\title{
Non-isothermal Reduction Kinetics of Gördes Laterite in CO Atmosphere
}

\author{
Gördes Lateritinin CO Atmosferinde İzotermal Olmayan İndirgenme Kinetiği
}

\author{
Nesibe DíLMAÇ 1 (iD \\ ${ }^{1}$ Çankırı Karatekin University, Chemical Engineering Department, 18100, Çankirl, Turkey
}

\begin{abstract}
The growing demand for nickel metal and the depletion of high-grade sulfide ore reserves have turned the direction of industry towards laterites which are not desirable as the primary source due to their low Ni content and more energy-intensive processing. Thus, alternative routes are essential for effectively processing these ores while reducing the costs and greenhouse gas emissions. Solid-state reduction followed by magnetic separation is an attractive option for recovering the nickel in laterites. Hereby, this study analyzed the non-isothermal reduction kinetics of nickel laterite from Gördes (Manisa, Turkey) by CO at different heating rates of 20,25,30,35, and $45^{\circ} \mathrm{C} / \mathrm{min}$. The activation energies were determined by Friedman (FR), KissingerAkahira-Sunose (KAS), and Flynn-Wall-Ozawa (FWO) methods, and the controlling mechanisms were determined by the Malek interpretation of the Sestak-Berggren Equation. The reduction process was divided into three stages which take place between "0 to 0.16 ", " 0.16 to 0.45 ", and " 0.45 to 0.7 " reduction degrees respectively according to the kinetic analysis results. The first stage was determined to be interface reaction controlled (with "Ea" of $53 \mathrm{~kJ} / \mathrm{mol}$ ), while the second and third were determined to be mixed controlled (with "Ea" of $126 \mathrm{~kJ} / \mathrm{mol}$ and $379 \mathrm{~kJ} / \mathrm{mol}$, respectively).
\end{abstract}

Keywords: Nickel, laterite, non-isothermal TGA, kinetic modeling, Sestak-Berggren equation

\section{Öz}

Nikel metaline yönelik her geçen gün artan talebe rağmen sülfit yataklarının tükeniyor oluşu sektörün yönünü düşük Ni içeriği ve yüksek enerji gerektirmesi dolayısıyla birincil kaynak olarak pek tercih edilmeyen laterit yataklarına çevirmiştir. Dolayısıyla hem maliyetleri hem de sera gazı emisyonları düşürerek bu cevherleri etkin şekilde işleyebilmek için alternatif yolların bulunması elzemdir. Lateritlerdeki nikelin kazanılması için katı faz indirgenmesi ve akabinde magnetik yolla ayırma cazip bir seçenektir. Bu nedenle bu çalışma Gördes lateritinin (Manisa, Türkiye) farklı 1sıtma hızlarında $\left(20,25,30,35\right.$, ve $45^{\circ} \mathrm{C} / \mathrm{dak}$.) izotermal olmayan indirgenme kinetiğini konu almıştır. Aktivasyon enerjileri Friedman (FR), Kissinger-Akahira-Sunose (KAS), ve Flynn-Wall-Ozawa (FWO) yöntemleriyle, hızı kontrol eden mekanizmalar ise Sestak-Berggren Eşitliğinin Malek yorumu ile belirlenmiş̧ir. İndirgenme prosesi, kinetik analiz sonuçlarına dayanılarak sırasıyla "0 ile 0,16", "0,16 ile 0,45", and "0,45 ile 0,7" indirgenme dereceleri arasında yer alan üç bölgeye ayrılmıştır. İlk bölgenin $53 \mathrm{~kJ} / \mathrm{mol}$ ' lük bir aktivasyon enerjisiyle, arayüz reaksiyon kontrolü altında gerçekleştiği, ikinci ve üçüncü bölgelerin ise sırasıyla $126 \mathrm{~kJ} / \mathrm{mol} \mathrm{ve} 379 \mathrm{~kJ} / \mathrm{mol}$ ' lik aktivasyon enerjisiyle, karışık kontrollü olarak gerçekleştiği belirlenmiştir.

Anahtar Kelimeler: Nikel, laterit, izotermal olmayan TGA, kinetik modelleme, Sestak-Berggren eşitliği

\section{INTRODUCTION}

Nickel is a crucial and strategic metal for the modern world since it is widely used for stainless steel production which accounts for two-thirds of annual nickel consumption [1], while the rest is utilized in aerospace and military industries, electrolytic plating, manufacturing of batteries, catalysts, high-temperature alloys, superalloys, coins, coatings, pigments, and ceramics [2]. The notable features of nickel such as good plasticity and ductility, superior corrosion, wear, and high-temperature resistance, good magnetic properties, and high strength spread its utilization, but mainly the increase in stainless steel production led to a substantial increase in global nickel production in recent years [3]. There are two main nickel sources, sulfide ores, and laterite ores. Although 70\% of land-based nickel ores are lateritic, $60 \%$ of industrial nickel production is derived from sulfide ores [4] due to fact that nickel in sulfide ores can be easily enriched and recovered. Lateritic ores are not preferable as a primary source for nickel production because of their low-grade and complex mineralogy which makes the production more costly and energy-consuming. However, continuous depletion of high-grade sulfides over the years and high demand for nickel metal have made laterites an attractive alternative for nickel production [5].

There are several hydrometallurgical, pyrometallurgical, and combined methods (such as atmospheric leaching, high-pressure acid leaching (HPAL), reductive roasting followed by ammonia leaching (Caron process), rotary kiln electric furnace process (RKEF or Elkem process) [6], direct reduction followed by magnetic separation process [7]) for extracting nickel from laterites since conventional mineral beneficiation techniques such as fine grinding or flotation are ineffective on these ores. However, hydrometallurgical processes require vast amounts of acid, while more than half of the known laterites are not convenient for the traditional pyrometallurgical processes 
due to their low Ni content. Moreover, both methods are massively energy-consuming. Therefore, it is inevitable to develop low-cost alternatives for processing laterites. One possible way may be producing a concentrate from the laterite by solid-state reduction which is performed at relatively lower temperatures compared to pyrometallurgical smelting, then physically separating the ferronickel [8]. In this regard, a comprehensive kinetic analysis is essential to constitute a theoretical reference for determining and optimizing the best processing conditions for prospective industrial applications.

In this paper, the non-isothermal reduction kinetics of Gördes laterite ore under $\mathrm{CO}$ atmosphere was investigated by TGA in line with the abovementioned motivation. The study is original in respect of enlighting the solid-state reduction kinetics of a Turkish laterite ore (Gördes, Manisa) using nonisothermal TGA. Moreover, it includes the application of the Sestak-Berggren equation for identifying the multiple controlling mechanisms in kinetic modeling of laterite reduction for the first time.

\section{MATERIALS AND METHODS}

The reduction experiments were conducted in a "TA Instruments SDT Q-600" thermalgravimetric analyzer at five heating rates $\left(20,25,30,35\right.$, and $45^{\circ} \mathrm{C} / \mathrm{min}$. $)$ up to $1173 \mathrm{~K}\left(900^{\circ} \mathrm{C}\right)$ under $\mathrm{CO}$ flow. An external mass flow controller was used to dilute the $\mathrm{N}_{2}$ stream with $\mathrm{CO}$ for obtaining the desired gas composition. The total flow rate was $100 \mathrm{ml} / \mathrm{min}$. and the composition was $50 \% \mathrm{CO}$ in $\mathrm{N}_{2}$ until the target temperature was achieved. The gas stream was switched to $\mathrm{N}_{2}$ for cooling the samples after the completion of the kinetic runs.

The laterite ore whose chemical composition is given in Table 1, was supplied from Gördes Mine (Manisa, Turkey) via Meta Nickel Cobalt Company. The ore samples were first dried in an oven at $105^{\circ} \mathrm{C}$ for 24 hours to remove the moisture, then crushed and sieved to a size range of about $120 \mu \mathrm{m}$. The samples were calcined at $1173 \mathrm{~K}\left(900{ }^{\circ} \mathrm{C}\right)$ for 18 hours and approximately $20 \mathrm{mg}$ of calcined sample was placed into the alumina crucible of the analyzer for each kinetic run.

Table 1. Chemical composition of Gördes laterite ore $(\%, w / w)$

\begin{tabular}{lllllllll}
\hline $\mathbf{F e}_{2} \mathbf{O}_{3}$ & $\mathbf{S i O}_{2}$ & $\mathrm{Al}_{2} \mathbf{O}_{3}$ & $\mathbf{C a O}$ & $\mathrm{NiO}$ & $\mathbf{M g O}$ & $\mathrm{Cr}_{2} \mathbf{O}_{3}$ & $\mathrm{SO}_{3}$ & Other \\
\hline 42.31 & 33.11 & 8.82 & 3.66 & 3.19 & 2.22 & 1.67 & 0.5 & 4.52 \\
\hline
\end{tabular}

The reduction of laterite ore under $\mathrm{CO}$ atmosphere follows the order given in Eq. (1) to Eq. (4).

$$
\begin{aligned}
& 3 \mathrm{NiFe}_{2} \mathrm{O}_{4} \rightarrow 3 \mathrm{NiO}+3 \mathrm{Fe}_{2} \mathrm{O}_{3} \\
& 3 \mathrm{NiO}+3 \mathrm{Fe}_{2} \mathrm{O}_{3}+4 \mathrm{CO} \rightarrow 3 \mathrm{Ni}+2 \mathrm{Fe}_{3} \mathrm{O}_{4}+4 \mathrm{CO}_{2} \\
& 2 \mathrm{Fe}_{3} \mathrm{O}_{4}+2 \mathrm{CO} \rightarrow 6 \mathrm{FeO}+2 \mathrm{CO}_{2} \\
& 6 \mathrm{FeO}+6 \mathrm{CO} \rightarrow 6 \mathrm{Fe}+6 \mathrm{CO}_{2}
\end{aligned}
$$

The conversion or reduction degree of the ore $(\alpha)$, can be obtained via Eq. (5) where " $\mathrm{m}_{(\mathrm{t})}$ " is the weight of the ore sample at any moment of the run, " $\mathrm{m}_{\mathrm{o}}$ " is the weight of the sample in its oxidized form, and " $m_{r} "$ is the weight of the sample in case of complete reduction.

$\alpha=\frac{m_{0}-m_{(t)}}{m_{0}-m_{r}}$

\subsection{Kinetic Analysis}

The rate of a solid-state reaction $(\mathrm{d} \alpha / \mathrm{dt})$ can be described by the well-known kinetic law

$\frac{d \alpha}{d t}=k(T) \cdot f(\alpha)$

where " $\alpha$ " is the conversion degree of the solid reactant, " $f(\alpha)$ " is the differential model function describing the mechanism, and " $\mathrm{k}(\mathrm{T})$ " is the temperature-dependent reaction rate constant. Combining Eq. (6) and the "Arrhenius equation" yields Eq. (7), $\frac{d \alpha}{d t}=A \cdot e^{\left(-\frac{E_{a}}{R \cdot T}\right)} \cdot f(\alpha)$

where "A" is the pre-exponential factor, "R" is the universal gas constant, " $\mathrm{E}_{\mathrm{a}}$ " is the activation energy, and " $\mathrm{T}$ " is the absolute temperature. By taking the natural logarithm of each side of Eq. (7) the model-free (isoconversional) Friedman's equation (FR) given in Eq. (8) is obtained.

$\ln \left(\frac{d \alpha}{d t}\right)=-\frac{E_{a}}{R \cdot T}+\ln (A \cdot f(\alpha))$

By inserting the linear heating rate $(\beta=\mathrm{dT} / \mathrm{dt})$ into the left-hand side of Eq. (8), Eq. (9) is obtained. In this way, one can obtain " $E_{a}$ " for a particular " $\alpha$ " without making any assumption on the reaction model from the negative slope of the straight line showing the variation of "ln[ $\beta$. $(\mathrm{d} \alpha / \mathrm{dT})] "$ against " $1 / \mathrm{T}$ " for different heating rates.

$\ln \left(\beta \cdot \frac{d \alpha}{d T}\right)=-\frac{E_{a}}{R \cdot T}+\ln (A \cdot f(\alpha))$

The non-isothermal kinetic data can also be handled by integral model-free methods in addition to the differential model-free Friedman method presented above. In this context, if both sides of Eq. (7) are divided by " $\beta$ " and rearranged, Eq. (10) is obtained where $" g(\alpha)$ " is the integral model function. 


$$
g(\alpha)=\int_{0}^{\alpha} \frac{d \alpha}{f(\alpha)}=\int_{0}^{T} \frac{A}{\beta} \cdot e^{\left(-\frac{E_{a}}{R \cdot T}\right)} \cdot d T
$$

"Ea/RT" in Eq. (10) can be replaced with "u" to express $" \mathrm{~g}(\alpha)$ " in a more general form as in Eq. (11).

$$
g(\alpha)=\frac{A \cdot E_{a}}{\beta \cdot R} \int_{\infty}^{u}\left(\frac{e^{-u}}{u^{2}}\right) d u=\frac{A \cdot E_{a}}{\beta \cdot R} \cdot p(u)
$$

The term "p(u)" appears in Eq. (11) is the "temperature or exponential integral" and it can solely be obtained by using various algebraic approximations since it has no analytical solution for nonisothermal conditions.

In integral model-free Flynn-Wall-Ozawa (FWO) method which employs Doyle's approximation for the solution of "p(u)", linear fitting of $" \ln (\beta)$ " versus "1/T" couples obtained at different heating rates for a particular conversion $(\alpha)$ gives a straight line with a slope of "-1.051 $\mathrm{E}_{\mathrm{a}} / \mathrm{R}$ " as seen on Eq. (12).

$$
\ln (\beta)=\ln \left(\frac{A \cdot E_{a}}{R \cdot g(\alpha)}\right)-5.331-1.051 \frac{E_{a}}{R \cdot T}
$$

In integral model-free Kissinger-Akahira-Sunose (KAS) method which utilizes Murray and White approximation for the solution of "p(u)", one can calculate " $E_{a}$ " from the slope of the straight line by plotting " $\ln \left(\beta / \mathrm{T}^{2}\right)$ " versus "1/T" couples obtained at different heating rates for a particular " $\alpha$ " (see Eq. (13)).

$\ln \left(\frac{\beta}{T^{2}}\right)=\ln \left(\frac{A \cdot R}{g(\alpha) \cdot E_{a}}\right)-\frac{E_{a}}{R \cdot T}$

Although model-free methods provide valuable information $\left(\mathrm{E}_{\mathrm{a}}\right)$ about the concerned reaction scheme, kinetic analysis remains incomplete without identifying the rate-controlling mechanism. To remedy this deficiency, Masterplots and Sestak-Berggren methods were adopted to determine the reaction models for each stage of the laterite reduction presented in this study. The Masterplots method depends on the comparison of the experimental master-plot with the theoretical master-plots to determine the reaction model. In this method, rational Doyle's approximation is used to solve "p(u)" given in Eq. (14)

$$
p(u)=0.00484 e^{-1.0516 u}
$$

Adopting $\alpha=0.5$ as the reference point, $" \mathrm{~g}(0.5)$ " can be expressed as in Eq. (15).

$g(0.5)=\frac{A \cdot E_{a}}{\beta \cdot R} \cdot p\left(u_{0.5}\right)$

After dividing Eq. (11) by Eq. (15), the integral masterplots equation can be obtained as in Eq. (16).

$$
\frac{g(\alpha)}{g(0.5)}=\frac{\left[A E_{a} / \beta R\right] \cdot p(u)}{\left[A E_{a} / \beta R\right] \cdot p\left(u_{0.5}\right)}=\frac{p(u)}{p\left(u_{0.5}\right)}
$$

where $" \mathrm{u}_{0.5}=\mathrm{Ea} / \mathrm{RT}_{0.5}$ " $\left(\mathrm{T}_{0.5}\right.$ is the temperature at $\alpha=$ $0.5)$, and $g(0.5)$ is the integral form of the reaction model at $\alpha=0.5$. Eq. (16) implies that, for a given $\alpha$, the experimental value of $" p(u) / p(0.5) "$ and the theoretically calculated value of $" \mathrm{~g}(\alpha) / \mathrm{g}(0.5)$ " should be equivalent if a proper kinetic model is chosen [9]. By extending this fact from a single conversion value to the entire scale, it can be concluded that the experimental master-plot ("p $(\mathrm{u}) / \mathrm{p}(0.5)$ versus $\alpha$ " plot) should largely coincide with the theoretical master-plot (" $\mathrm{g}(\alpha) / \mathrm{g}(0.5)$ versus $\alpha$ " plot) in which " $\mathrm{g}(\alpha)$ " represents the controlling mechanism for the concerned reaction. The first step of enlighting the reaction mechanism via Masterplots method is obtaining a number of "g( $\alpha) / g(0.5)$ versus $\alpha$ " plots -i.e. theoretical masterplots- through processing the available kinetic data ( $\alpha$ versus $t$ or $T$ values) with the various integral model functions given in Table 2. Afterward, the experimental master-plot can be obtained by processing the kinetic data ( $\alpha$ versus T values) with Eq. (17) where " $E_{a}$ " is the mean activation energy which was previously calculated by model-free methods.

$\frac{p(u)}{p\left(u_{0.5}\right)}=e^{1.0516 \cdot\left(u_{0,5}-u\right)}=e^{1.0516 \cdot\left(E_{a} / R\right) \cdot\left(T^{-0.5}-T^{-1}\right)}$

Finally, the model equation belonging to the theoretical master-plot which largely overlaps with the experimental master-plot is concluded to represent the concerned reaction best [10],[11].

It should be emphasized that, although the Masterplots method offers quite accurate models for single-step reactions progressing with a reasonably stable " $E_{a} "$ value, it may be insufficient in modeling multi-step reactions which include the variation of controlling mechanism and " $E_{a}$ " throughout the reaction. In such cases, the kinetic investigation should be deepened to reveal the effect of each controlling mechanism on the reaction rate.

In this respect, it is highly recommended to use SestakBerggren method which provides enough flexibility to represent complex reaction schemes with overlapping controlling mechanisms. According to this method, an empirical model function given in Eq. (18) can fit any reaction mechanism with the proper combination of kinetic exponents "n", "m", and "p" [12], [13].

$f(\alpha)=(1-\alpha)^{n} \alpha^{m}[-\ln (1-\alpha)]^{p}$

$(1-\alpha)^{\mathrm{n}}, \alpha^{\mathrm{m}}$, and $[-\ln (1-\alpha)]^{\mathrm{p}}$ terms in Eq. (18) correspond interface reaction, diffusion, and nucleation controlled decomposition mechanisms, respectively.

Malek [14] proposed a simple method to determine the kinetic exponents in Sestak-Berggrn equation in which a new "y( $\alpha)$ " function is defined by rearranging Eq. (7) as seen below ( $E_{0}$ appearing in Eq. (19) is the mean activation energy). 


$$
y(\alpha)=\left(\frac{d \alpha}{d t}\right)_{\alpha} e^{\left(\frac{E_{0}}{R T_{\alpha}}\right)}=A f(\alpha)
$$

According to Eq. (19), the shape of the theoretical "A.f $(\alpha)$ " curve should be consistent with the experimental " $\mathrm{y}(\alpha)$ " curve since "A" is constant. After inserting Eq. (18) into Eq. (19) as in Eq. (20), the kinetic exponents ("n", "m", and "p") can be obtained by non-linear fitting of experimental "y $(\alpha)$ " values into the Sestak-Berggren equation. This can be handled by using various software such as Excel Equation Solver, Mathcad, or Matlab, etc. which can optimize the values of "A", "n", "m", and "p" to catch the best overlap between the graphical representations of both sides of Eq. (20).

$$
\left(\frac{d \alpha}{d t}\right)_{\alpha} e^{\left(\frac{E_{0}}{R T_{\alpha}}\right)}=A(1-\alpha)^{n} \alpha^{m}[-\ln (1-\alpha)]^{p}
$$

Table 2. Common $f(\alpha)$ and $g(\alpha)$ expressions for gas-solid reactions

\begin{tabular}{lccc}
\hline \multicolumn{1}{c}{ Reaction Model } & Symbol & $\mathbf{F}(\alpha)=(\mathbf{1} / \mathbf{k} \mathbf{i}) \cdot(\mathbf{d} \alpha / \mathbf{d t})$ & $\mathbf{G}(\alpha)=\mathbf{k} \mathbf{i . t}$ \\
\hline 1-D diffusion model & $\mathrm{D}_{1}(\alpha)$ & $1 /(2 \alpha)$ & $\alpha^{2}$ \\
\hline 2-Ddiffusion model & $\mathrm{D}_{2}(\alpha)$ & $(-\ln (1-\alpha))^{-1}$ & $(1-\alpha) \ln (1-\alpha)+\alpha$ \\
\hline 3-D diffusion model (Jander eq.) & $\mathrm{D}_{3}(\alpha)$ & $(3 / 2)(1-\alpha)^{2 / 3}\left(1-(1-\alpha)^{1 / 3}\right)$ & $(1-2 \alpha / 3)-(1-\alpha)^{2 / 3}$ \\
\hline 3-D diffusion model (Ginstein-Brounshtein eq.) & $\mathrm{D}_{4}(\alpha)$ & $(3 / 2)\left((1-\alpha)^{-1 / 3}-1\right)$ & $\alpha$ \\
\hline $\begin{array}{l}\text { 0-order contraction or phase -boundary } \\
\text { controlled (infinite slabs) model }\end{array}$ & $\mathrm{F}_{0}(\alpha)$ & 1 & $-\ln (1-\alpha)$ \\
\hline $\begin{array}{l}\text { 1-order reaction (unimolecular decay law) or } \\
\text { one-dimensional growth of nuclei model }\end{array}$ & $\mathrm{F}_{1}(\alpha)$ & $1-\alpha$ & $1-(1-\alpha)^{1 / 2}$ \\
\hline $\begin{array}{l}\text { 2-D contraction or phase -boundary controlled } \\
\text { (contracting cylinder) model }\end{array}$ & $\mathrm{R}_{2}(\alpha)$ & $2(1-\alpha)^{1 / 2}$ & $1-(1-\alpha)^{1 / 3}$ \\
\hline $\begin{array}{l}\text { 3-D contraction or phase -boundary controlled } \\
\text { (contracting sphere) model }\end{array}$ & $\mathrm{R}_{3}(\alpha)$ & $3(1-\alpha)^{2 / 3}$ & $(-\ln (1-\alpha))^{1 / 2}$ \\
\hline $\begin{array}{l}\text { 2-D growth of nuclei or Avrami-Erofe'ev } \\
\text { (m=2) model }\end{array}$ & $\mathrm{A}_{2}(\alpha)$ & $2(1-\alpha)(-\ln (1-\alpha))^{1 / 2}$ & $(-\ln (1-\alpha))^{1 / 3}$ \\
\hline $\begin{array}{l}\text { 2-D growth of nuclei or Avrami-Erofe'ev } \\
\text { (m=3) model }\end{array}$ & $\mathrm{A}_{3}(\alpha)$ & $3(1-\alpha)(-\ln (1-\alpha))^{2 / 3}$ & \\
\hline
\end{tabular}

\section{RESULTS AND DISCUSSION}

Figure 1 shows the variation of the reduction degree of laterite samples with the temperature at five different heating rates i.e $20,25,30,35$, and $45^{\circ} \mathrm{C} / \mathrm{min}$. As seen from the figure, complete reduction of laterite was solely achieved at 35 and $45^{\circ} \mathrm{C} / \mathrm{min}$., while the highest achievable conversion decreased to $0.7-0.8$ interval for the lower heating rates. This fact may be attributed to the thermal hysteresis phenomenon frequently encountered in TGA studies which leads the reaction zones to reach higher temperatures as the heating rate increases [13],[15].

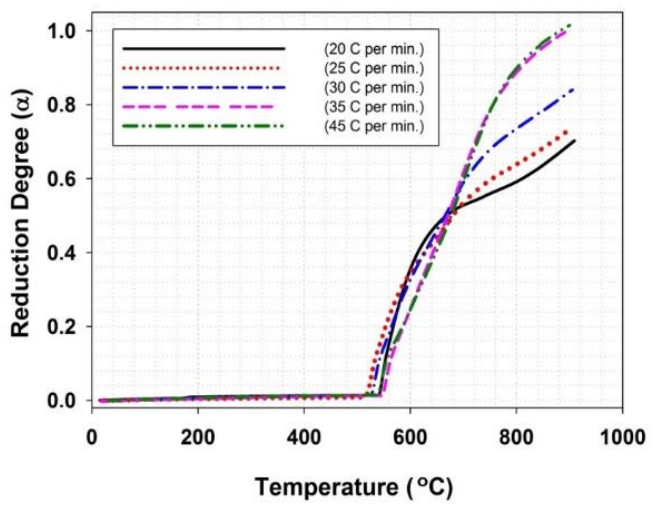

Figure 1. " $\alpha$ " vs " $T$ " graphs for laterite ore at different heating rates

As the first step of kinetic analysis, " $E_{a}$ " values for the entire reduction were calculated by using integral model-free FWO and KAS methods. For that purpose,
14 temperature values matching with 14 " $\alpha$ " levels varying from 0.05 to 0.7 (with $5 \%$ increment) were extracted from kinetic data for each heating rate and processed according to Eq. (12) and Eq. (13), respectively [16]. The nonisothermal data was also handled by the differential model-free FR method according to Eq. (9). With the help of the straight lines seen in Figure 2, mean " $\mathrm{E}_{\mathrm{a}}$ " values were calculated as $182 \mathrm{~kJ} / \mathrm{mol}, 167 \mathrm{~kJ} / \mathrm{mol}$, and $209 \mathrm{~kJ} / \mathrm{mol}$ by $\mathrm{FWO}$, $\mathrm{KAS}$, and FR methods respectively. " $\mathrm{E}_{\mathrm{a}}$ " values for reduction degrees greater than 0.7 could not be determined because the slopes of the straight lines seen in Figure 2 changed from negative to positive.

Besides the mean values calculated by isoconversional methods (see Figure 2), the variation of " $E_{a}$ " during the gaseous reduction of laterite is also illustrated in Figure 3. It should be emphasized that the appearance of Figure 3 is in great accordance with a previous TGA study [17] in which the laterite ore was reduced by carbon and the non-stable trend of activation energy was attributed to the changing of the reaction mechanism throughout the reduction. Thus, the increasing progress seen on activation energy in the current study was evaluated as evidence for the multistep reaction kinetics. To support this argument, "d $\alpha / \mathrm{dt}$ " vs " $\alpha$ " curves showing the variation of the reaction rates during the tests were examined and the reduction pathway was divided into 3 distinct regions [1],[2] each has its own rate characteristics (see Figure 4). 


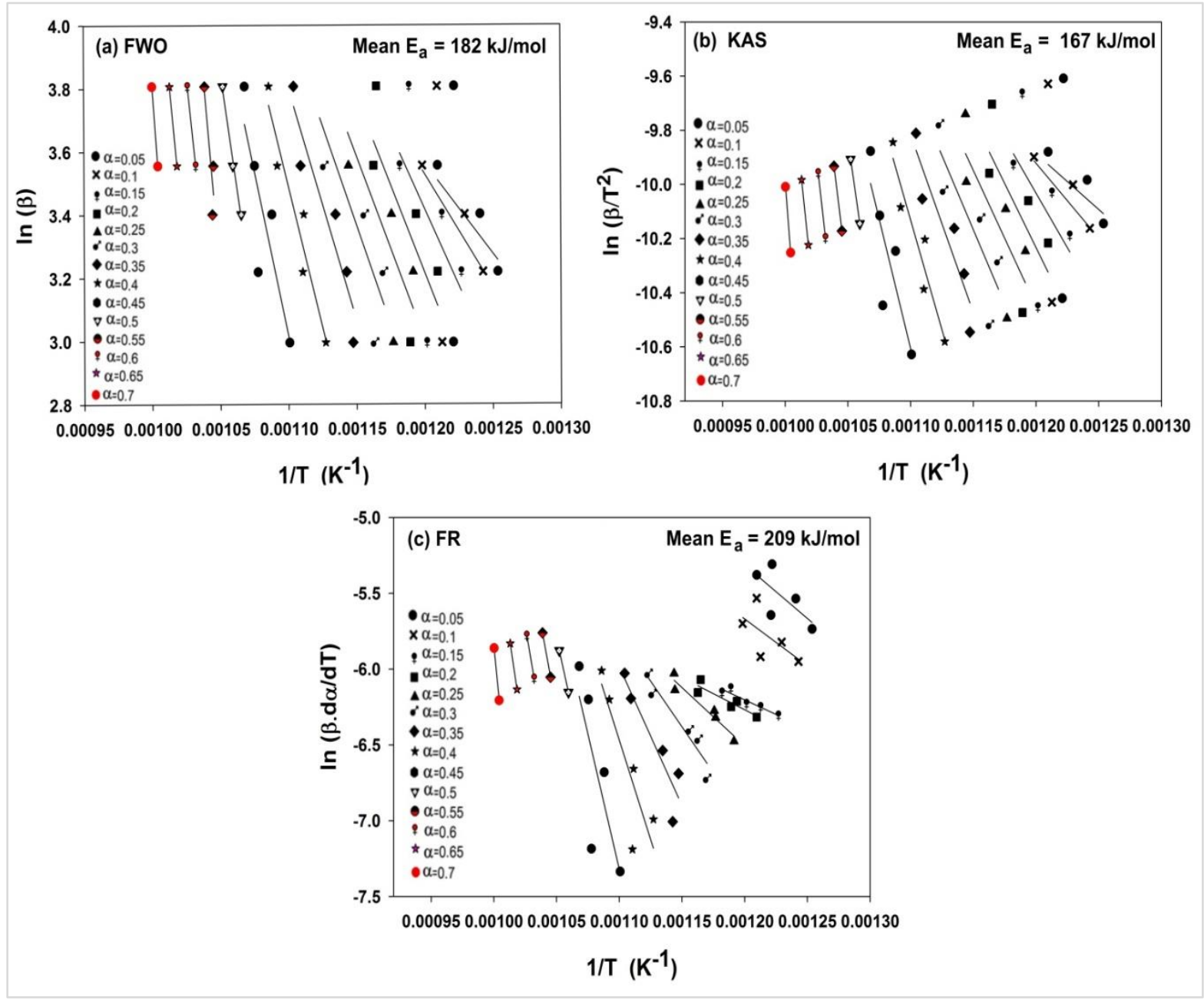

Figure 2. (a) FWO (b) KAS (c) FR graphs for non-isothermal reduction of laterite ore.

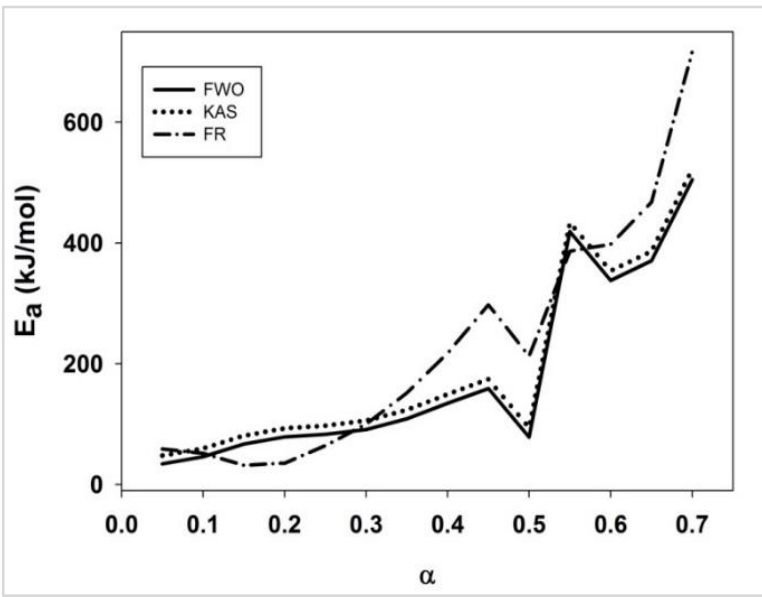

Figure 3. Variation of " $E_{a}$ " throughout the reduction

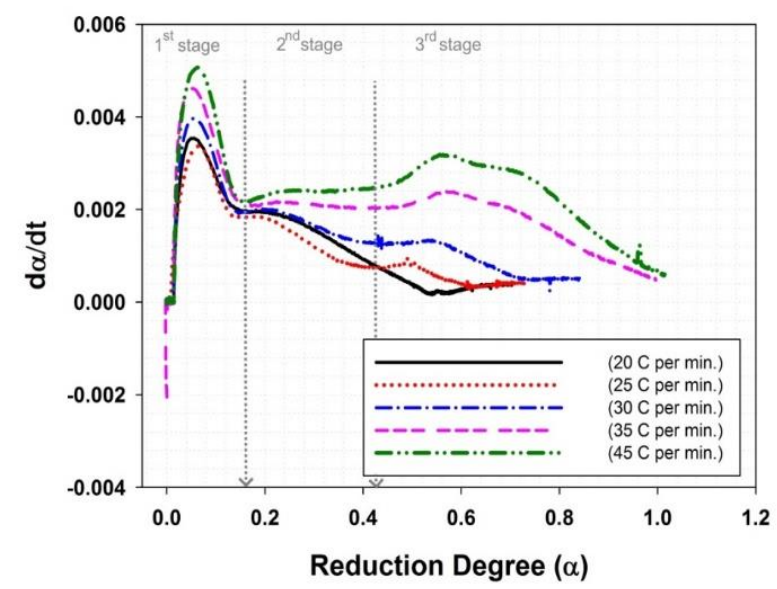

Figure 4. Variation of the reaction rates $(\mathrm{d} \alpha / \mathrm{dt})$ during the TGA tests 
To determine the temperature ranges corresponding to each stage, the TGA curve of the test performed at 30 ${ }^{\circ} \mathrm{C} / \mathrm{min}$. was examined. Using the weight loss values tagged on Figure 5 and keeping in mind that the complete reduction of calcined Gördes laterite results in $15 \%$ weight loss, 4 temperatures $(525,558,650$, and $780{ }^{\circ} \mathrm{C}$ ) corresponding to $0,0.16,0.45$, and 0.7 conversion levels were determined as the limits separating the reduction stages. Figure 1 along with three DTG peak temperatures seen in Figure 5 (534, 565 , and $680^{\circ} \mathrm{C}$ ) also verified the temperature ranges as; $" 525^{\circ} \mathrm{C}$ to $558{ }^{\circ} \mathrm{C}$ ", $" 558{ }^{\circ} \mathrm{C}$ to $650{ }^{\circ} \mathrm{C}$ " and $" 650{ }^{\circ} \mathrm{C}$ to $780{ }^{\circ} \mathrm{C}$ " for the $1^{\text {st }}, 2^{\text {nd, }}$ and $3^{\text {rd }}$ reduction stages respectively. Thus, it was concluded that the reduction of laterite by $\mathrm{CO}$ consisted of 3 regions which took place between "0 to 0.16 ", "0.16 to 0.45 ", and "0.45 to 0.70 " conversion intervals.

After determining the reduction stages, the kinetic data belong to the test performed at $30{ }^{\circ} \mathrm{C} / \mathrm{min}$. was processed by the Masterplots method to identify the most probable controlling mechanism for each region. Figure 6 shows the comparison of the experimental master-plot ("p $\left.(\mathrm{u}) / \mathrm{p}(0.5)^{\prime \prime}\right)$ with the theoretical masterplots ("g( $\alpha) / g(0.5) ")$ created by the most common models given in Table 2.
As can be seen from Figure 6, there is substantial deviation and dissonance between the experimental and theoretical master-plots which indicates the presence of multiple controlling mechanisms, especially in the $2^{\text {nd }}$ and $3^{\text {rd }}$ stages. To be more clear, the stages of the reduction of Gördes laterite can not be described by a single controlling mechanism.

To reveal the individual contributions of coinciding mechanisms in each reduction stage, the kinetic data belong to the test performed at $30{ }^{\circ} \mathrm{C} / \mathrm{min}$. was processed by Malek's method. Within this context, "y( $\alpha)$ " vs " $\alpha$ " curves were obtained by using mean activation energy values of $53 \mathrm{~kJ} / \mathrm{mol}, 126 \mathrm{~kJ} / \mathrm{mol}$, and $379 \mathrm{~kJ} / \mathrm{mol}$ (see Figure 3 ) for the $1^{\text {st }}, 2^{\text {nd }}$, and $3^{\text {rd }}$ reduction stages, respectively. Afterward, the righthand side of Eq. (26) -which includes Sestak-Berggren equation- was optimized via Excel Equation Solver by starting with initial guess values of "A", "n", "m", and "p". At the end of the optimization process, the closest Sestak-Berggren curve to Malek's curve and related "A", "n", "m", and "p" values were obtained for each stage as seen in Figure 7. The results verified the multiple controlling mechanisms in all stages since at least 2 of the kinetic exponents ("n", "m", and "p") were different from zero.

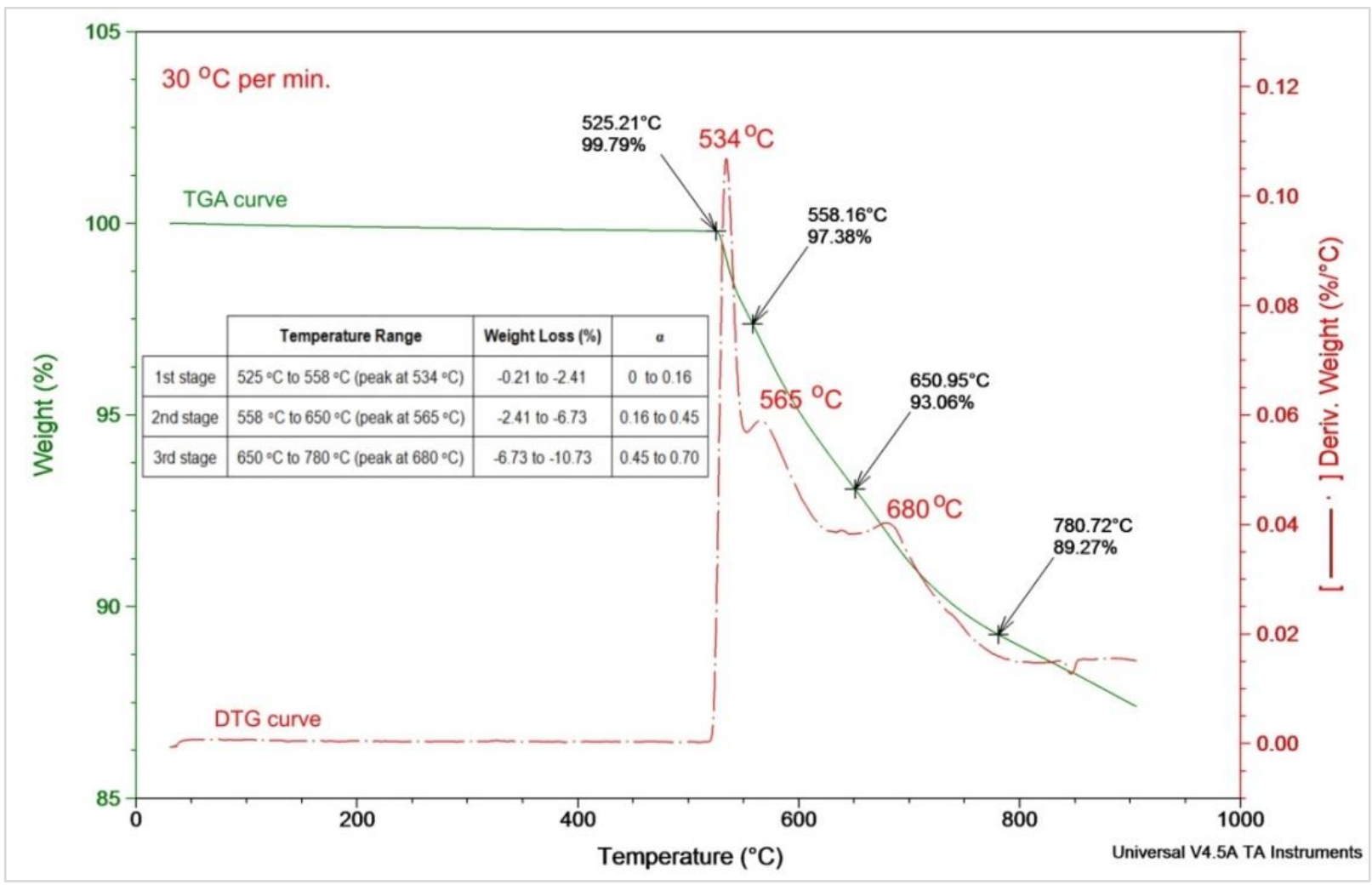

Figure 5. Overlaid TGA and DTG curve for the test performed at $30^{\circ} \mathrm{C} / \mathrm{min}$. 


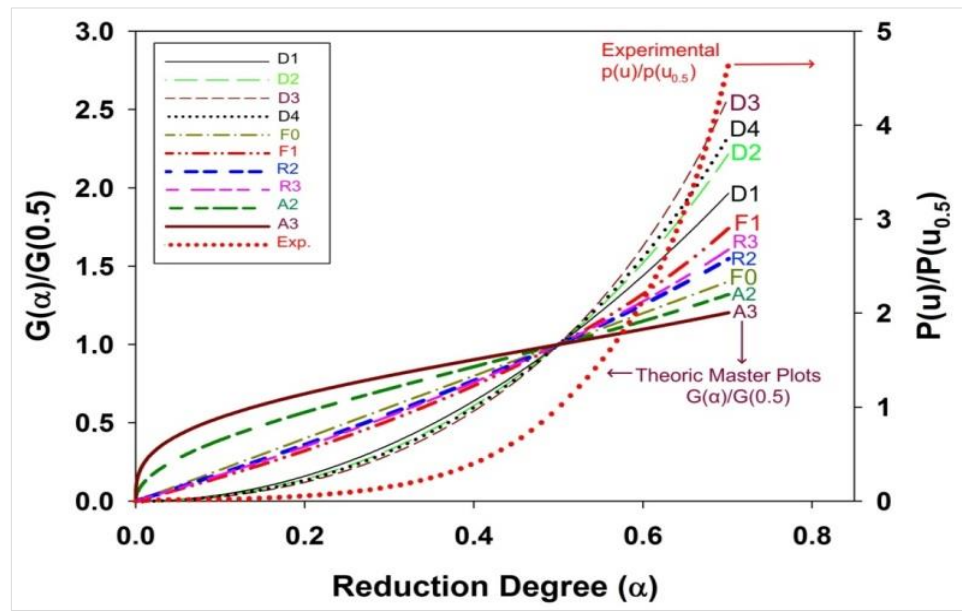

Figure 6. Comparison of theoretical master-plots with the experimental master-plot

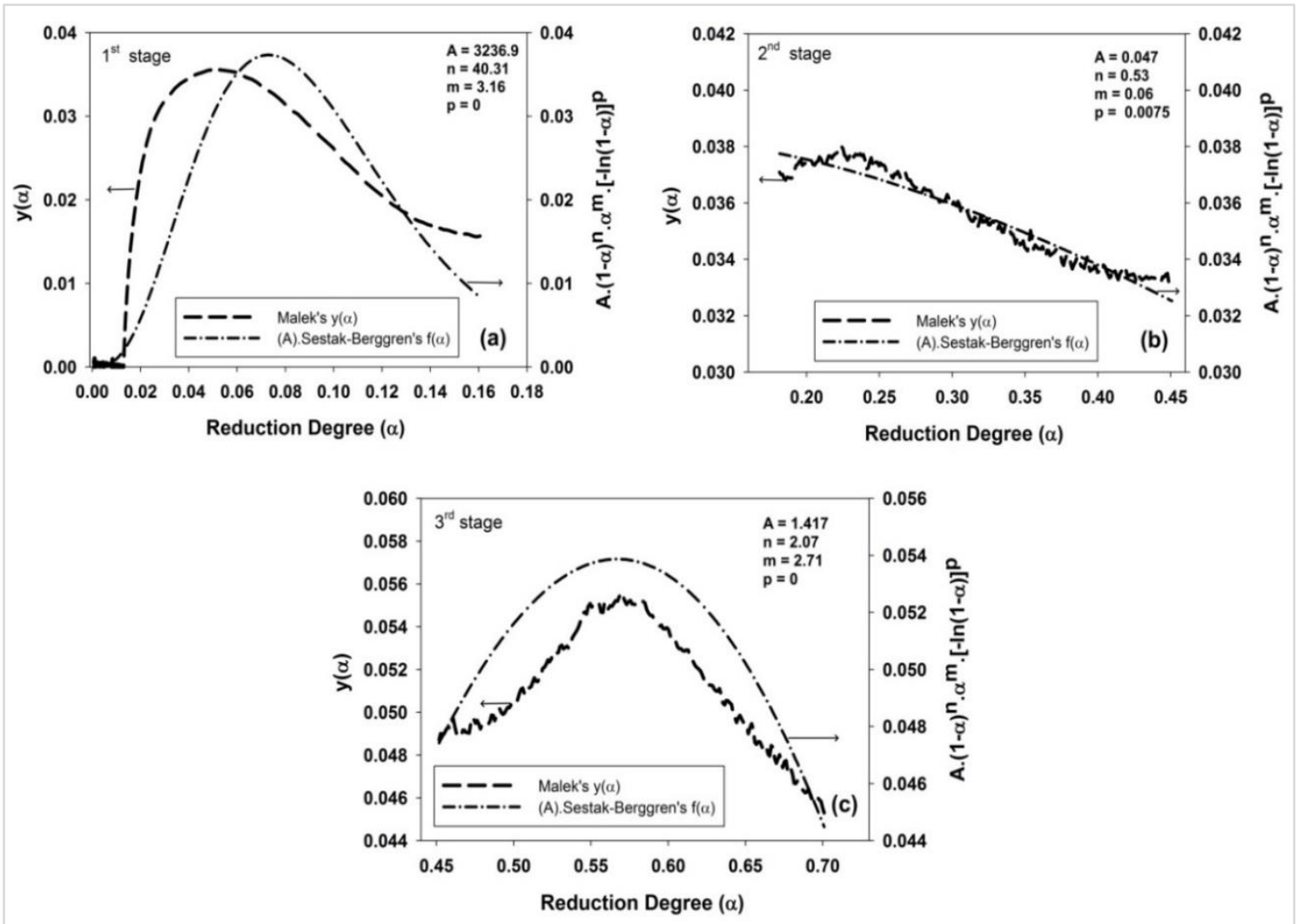

Figure 7. Determination of kinetic exponents in Sestak-Berggren equation for (a) $1^{\text {st }}$ (b) $2^{\text {nd }}$ (c) $3^{\text {rd }}$ stages of the reduction via Malek method

Figure 7 demonstrates that, although all stages of the reduction were under the collaborative control of the interface reaction and diffusion mechanisms, the effect of the reaction control was more explicit in the $1^{\text {st }}$ stage since " $n$ " in Figure 7 (a) was far bigger than "m". According to the common view in the related literature, $\mathrm{NiO}$ is firstly reduced in $\mathrm{Fe}-\mathrm{Ni}-\mathrm{O}$ systems, then the metallic nickel uses iron as a carrier to form $\mathrm{Fe}-\mathrm{Ni}$ alloy [18]. Therefore, the weight losses at the beginning of the reduction stem from the decomposition of trevorite $\left(\mathrm{NiFe}_{2} \mathrm{O}_{4}\right)$ into individual metal oxides (Eq. (1)), and the subsequent reduction of the said oxides $\left(\mathrm{NiO} / \mathrm{Fe}_{2} \mathrm{O}_{3}\right)$ into metallic nickel and magnetite
$\left(\mathrm{Ni} / \mathrm{Fe}_{3} \mathrm{O}_{4}\right)$ as in Eq. (2) [19]. It is highly probable that these 2 important transformations are also responsible for the dominant reaction control in the $1^{\text {st }}$ stage of the current study. Moreover, since the temperature range related to this stage $\left(525^{\circ} \mathrm{C}\right.$ to $\left.558{ }^{\circ} \mathrm{C}\right)$ is quite low for accelerating the abovementioned solid-state transformations, it is usual for the $1^{\text {st }}$ stage of the Gördes laterite reduction to be controlled by the interface reaction mechanism.

In the rest of the reduction, the effect of the interface reaction control steadily decreased in favor of the diffusion control and both became almost equal 
towards the end of the process (see Figure 7 (b) and (c)). Even the nucleation mechanism slightly contributed to the overall control with a "p" value of 0.0075 in the $2^{\text {nd }}$ stage. The presence of nucleation in this stage may be attributed to the slow formation of wustite $(\mathrm{FeO})$ nuclei emerged by magnetite $\left(\mathrm{Fe}_{3} \mathrm{O}_{4}\right)$ reduction (Eq. (3)). The literature [2], [17], [19], [20], [21] relates the weight losses in the $2^{\text {nd }}$ stage of the laterite reduction with " $\mathrm{Fe}_{3} \mathrm{O}_{4}$ to $\mathrm{FeO}$ " transformation which causes a decrease in the reaction rate (The formation of hardly reducible compounds, such as hercynite $\left(\mathrm{FeAl}_{2} \mathrm{O}_{4}\right)$ and fayalite $\left(\mathrm{Fe}_{2} \mathrm{SiO}_{4}\right)$ may also be responsible for the deceleration). Therefore, it is convenient to associate the mixed control in the $2^{\text {nd }}$ stage of the Gördes laterite reduction mainly with the reduction of magnetite to wustite.

After the completion of the wustite reduction $(\alpha>$ 0.45 ), the reaction rate slightly increased (see Figure 4 ) probably due to the catalytic effect of the metallic iron demonstrating that the $3^{\text {rd }}$ stage of the Gördes laterite reduction mainly included the "FeO to $\mathrm{Fe}^{\prime}$ transformation (Eq. (4)). "2.07", "2.71", and "0" values calculated for "n", "m", and "p" in that stage (see Figure 7(c)) implied that nucleation was no more effective and the process was mainly controlled by the combination of interface reaction and diffusion mechanisms. The relatively high temperature compared to the $1^{\text {st }}$ and $2^{\text {nd }}$ stages $\left(650{ }^{\circ} \mathrm{C}\right.$ to $\left.780{ }^{\circ} \mathrm{C}\right)$ lessened the impact of the interface reaction control, while the advanced conversion of the solid particles intensified the impact of the diffusion control.

Although there are a considerable amount of studies in the literature supporting the findings of the current study, especially a few will be emphasized here. For instance, Lv et al. (2018) [1] investigated the nonisothermal reduction kinetics of calcined laterite ore from Philippines (20 mg with $1.81 \% \mathrm{Ni}$ and $17.87 \% \mathrm{Fe}$ ) by graphite under $\mathrm{Ar}$ atmosphere $(20 \mathrm{ml} / \mathrm{min})$ at different heating rates $\left(10,15\right.$ and $20^{\circ} \mathrm{C} / \mathrm{min}$.) from ambient temperature to $1773 \mathrm{~K}\left(1500^{\circ} \mathrm{C}\right)$ in TGA. The kinetic data were analyzed by the KAS method and the process is determined to advance with highly variable "Ea" (mean $340 \mathrm{~kJ} / \mathrm{mol}$ for the whole process) indicating multistep reduction. With the help of the "d $\alpha /$ dt vs $\alpha$ " graph (which looks very similar to Figure 4 of the current study), the reduction process was divided into 3 stages according to the conversion as $\alpha=$ $0-0.45, \alpha=0.45-0.75$, and $\alpha=0.75-1$, respectively. Coats-Redfern method was utilized to identify the individual mechanisms controlling each stage. 2D and 3D diffusion control mechanisms were determined for the first and the second stages respectively, while chemical reaction control was determined for the last stage. Due to the utilization of solid reductant, the limits of the stages are wider compared to the current study. Besides, since the Coats-Redfern method was utilized for modeling, only the most dominant mechanism controlling each stage was declared and the contributions of the other potential mechanisms were disregarded.

In another study by the same investigators ( $\mathrm{Lv}$ et al., 2017) [17], the same ore was reduced using high purity carbon powder using the same experimental parameters. In that study, the limits of the reduction stages were determined as $\alpha=0-0.40, \alpha=0.40-0.70$, and $\alpha=0.70-0.9$ with mean " $\mathrm{E}_{\mathrm{a}}$ " values of $60 \mathrm{~kJ} / \mathrm{mol}$, $137 \mathrm{~kJ} / \mathrm{mol}$, and $383 \mathrm{~kJ} / \mathrm{mol}$, respectively. It is noteworthy that the said values are very close to the ones found in the current study $(53 \mathrm{~kJ} / \mathrm{mol}, 126 \mathrm{~kJ} / \mathrm{mol}$, and $379 \mathrm{~kJ} / \mathrm{mol}$ for the first, second, and third stages of reduction respectively). Moreover, the " $E_{a}$ vs $\alpha$ " graph in the abovementioned study is very similar to Figure 3 of the current study. Another common point, the first stage was determined to be controlled by chemical reaction, but the Malek interpretation of the Masterplots method was inadequate to model the second and third stages.

In earlier studies by Jankovic et al. (2007, 2008) [22], [23], the non-isothermal reduction kinetics of synthetic nickel oxide $(25 \mathrm{mg}$ ) prepared by sol-gel technique was investigated by TGA at different heating rates $(2.5,5$, 10 , and $20^{\circ} \mathrm{C} / \mathrm{min}$.) from ambient temperature to 1773 $\mathrm{K}\left(1500{ }^{\circ} \mathrm{C}\right)$ under $100 \% \mathrm{H}_{2}$ atmosphere (100 $\left.\mathrm{ml} / \mathrm{min}\right)$. The kinetic data were analyzed by FR, KAS, FWO, Kissinger, Stationary Point, and Invariant Kinetic Parameters methods and the process was determined to advance with an almost constant "Ea" value (mean 90 $\mathrm{kJ} / \mathrm{mol}$ for the whole process) probably due to the lack of other oxides (such as $\mathrm{Fe}_{2} \mathrm{O}_{3}$ ) in the solid sample. In other words, since the sample used in the study was high purity $\mathrm{NiO}$, the reduction did not take place in a multistep manner in which the "Ea" varies with the conversion and also with the type of the converted specie. The authors used Malek interpretation of Sestak-Berggren method for enlighting the mechanism and obtained $f(\alpha)=\alpha^{0.63}$. (1- $\left.\alpha\right)^{1.39}$ equation to represent the single step reduction.

In the light of the supporting literature and the findings of the current study, the multistep reduction kinetics of Gördes laterite with multiple controlling mechanisms in each stage can be formulated as below;

$$
\begin{aligned}
& 1^{\text {st }} \text { stage : } \\
& \frac{d \alpha}{d t}=3236.9\left(s^{-1}\right) \cdot e^{\frac{-53000(\mathrm{~J} / \mathrm{mol})}{8.314(\mathrm{~J} / \mathrm{mol} \cdot \mathrm{K}) \cdot T}} \cdot(1-\alpha)^{40.31} \cdot \alpha^{3.16} \\
& 2^{\text {nd }} \text { stage : } \\
& \frac{d \alpha}{d t}=0.047\left(s^{-1}\right) \cdot e^{\frac{-126000(\mathrm{~J} / \mathrm{mol})}{8.314(\mathrm{~J} / \mathrm{mol} . \mathrm{K}) \cdot T}} \\
& \times(1-\alpha)^{0.53} \cdot \alpha^{0.06} \cdot(-\ln (1-\alpha))^{0.0075}
\end{aligned}
$$

$3^{\text {rd }}$ stage :

$\frac{d \alpha}{d t}=1.417\left(s^{-1}\right) \cdot e^{\frac{-379000(\mathrm{~J} / \mathrm{mol})}{8.314(J / m o l . K) \cdot T}} \cdot(1-\alpha)^{2.1} \cdot \alpha^{2.71}$ 


\subsection{Conclusions}

- The reduction of Gördes laterite by $\mathrm{CO}$ is a complex, multistep reaction including multiple controlling mechanisms in each stage.

- The $1^{\text {st }}$ stage which takes place at "0 to 0.16 " conversion interval $\left(525{ }^{\circ} \mathrm{C}-558{ }^{\circ} \mathrm{C}\right)$ includes the decomposition of trevorite $\left(\mathrm{NiFe}_{2} \mathrm{O}_{4}\right)$ and subsequent reduction of $\mathrm{NiO}$ and $\mathrm{Fe}_{2} \mathrm{O}_{3}$ to $\mathrm{Ni}$ and $\mathrm{Fe}_{3} \mathrm{O}_{4}$. The interface reaction control dominates this stage with a convenient " $\mathrm{E}_{\mathrm{a}}$ " value of $53 \mathrm{~kJ} / \mathrm{mol}$.

- The $2^{\text {nd }}$ stage which takes place at "0.16 to $0.45^{\prime}$ conversion interval $\left(558{ }^{\circ} \mathrm{C}-650^{\circ} \mathrm{C}\right)$ mainly includes the reduction of $\mathrm{Fe}_{3} \mathrm{O}_{4}$ to $\mathrm{FeO}$. Due to the slow formation of wustite nuclei in this stage, the reaction rate is significantly slow. Moreover, in addition to the interface reaction and diffusion mechanisms, even the nucleation slightly contributes to the overall control. The " $\mathrm{E}_{\mathrm{a}}$ " value of $126 \mathrm{~kJ} / \mathrm{mol}$ is compatible with the mixed control in this stage.

- The $3^{\text {rd }}$ stage which takes place at "0.45 to $0.7^{\prime \prime}$ conversion interval $\left(650^{\circ} \mathrm{C}-780{ }^{\circ} \mathrm{C}\right)$ mainly includes the reduction of $\mathrm{FeO}$ to $\mathrm{Fe}$. The reaction rate in this region is slightly bigger compared to the $2^{\text {nd }}$ stage due to the catalytic effect of the freshly formed metallic iron. The interface reaction and diffusion mechanisms have almost equal impact on control (the diffusion control is a bit more effective since"m" (2.71) > "n" (2.07) ) due to the increased temperature and advanced conversion of the solid. Since solid-state diffusioncontrolled processes are characterized by high activation energy values in the literature, the " $E_{a}$ " value calculated as $379 \mathrm{~kJ} / \mathrm{mol}$ for this stage also supports the superiority of the diffusion mechanism.

The findings of the current study are meaningful for softwares such as Computational Fluid Dynamics (CFD) that can be used to develop a possible alternative process involving the processing of Gördes laterite by solid state reduction.

\subsection{Acknowledgments}

This research did not receive any specific grant from funding agencies in the public, commercial, or not-forprofit sectors. The author is grateful to R\&D specialist Bahar EROL and R\&D manager Nuray DEMİREL and META NIKKEL KOBALT A.Ş. (Meta Nickel Cobalt Company) for supplying the laterite ore samples from Gördes mine.

\section{REFERENCES}

[1] Lv, X., Lv,W., You, Z., Lv, X., \& Bai, C. (2018). Non-isothermal kinetics study on carbothermic reduction of nickel laterite ore. Powder Technol., 340, 495-501.

[2] Li, B., Ding, Z., Wei, Y., Wang, H., Yang, Y., \& Barati, M. (2018). Kinetics of reduction of lowgrade nickel laterite ore using carbon monoxide.
Metall. Mater. Trans. B-Process Metall. Mater. Process Sci., 49, 3067-3073.

[3] Yang, S., Du, W., Shi, P., Shangguan, J., Liu, S., Zhou, C. et al. (2016). Mechanistic and kinetic analysis of $\mathrm{Na}_{2} \mathrm{SO}_{4}$-Modified laterite decomposition by thermogravimetry coupled with mass spectrometry. PLoS One, 11(6), 1-21.

[4] Zhang, Y., Cui, K., Wang, J., Wang, X., Qie, J., $\mathrm{Xu}$, Q., et al. (2020). Effects of direct reduction process on the microstructure and reduction characteristics of carbon-bearing nickel laterite ore pellets. Powder Technol., 376, 496-506.

[5] Elliott, R., \& Pickles, C. A. (2017). Thermodynamic analysis of the selective reduction of a nickeliferous limonitic laterite ore by hydrogen. High Temp. Mater. Proc., 36(8), 835-846.

[6] Wang, X., Sun, T., Chen, C., \& Hu, T. (2017). Current studies of treating processes for nickel laterite ores, Advances in Computer Science Research, 70, 139-152.

[7] Zhu, D., Pan, L., Guo, Z., Pan, J., \& Zhang, F. (2019). Utilization of limonitic nickel laterite to produce ferronickel concentrate by the selective reduction-magnetic separation process. $A d v$. Powder Technol., 30, 451-460.

[8] Elliott, R., Pickles, C. A., \& Forster, J. (2016). Thermodynamics of the reduction roasting of nickeliferous laterite ores. J. Miner. Mater. Charact. Eng., 4, 320-346.

[9] Ma, Y., Niu, R., Wang, X., Wang, Q., Wang, X., \& Sun, X. (2014). Co-pyrolysis behaviour and kinetic of two typical solid wastes in China and characterisation of activated carbon prepared from pyrolytic char. Waste Manag. Res., 32(11), 1123-1133.

[10] Bartocci, P., Tschentscher, R., Stensrød, R. E., Barbanera, M., \& Fantozzi, F. (2019). Kinetic analysis of digestate slow pyrolysis with the application of the master-plots method and independent parallel reactions scheme. Molecules, 24(9), 1-15.

[11] Wang, Z., Xie, T., Ning, X., Liu, Y., \& Wang, J. (2019).Thermal degradation kinetics study of polyvinyl chloride (PVC) sheath for new and aged cables. Waste Manag., 99, 146-153.

[12] Yeo, J. Y., Chin, B. L. F., Tan, J. K., \& Loh, Y. S. (2019). Comparative studies on the pyrolysis of cellulose, hemicellulose, and lignin based on combined kinetics. J. Energy Inst., 92(1), 27-37.

[13] Han, J., Sun, Y., Guo, W., Deng, S., Hou, C., Qu, L., et al. (2019). Non-isothermal thermogravimetric analysis of pyrolysis kinetics of four oil shales using Sestak-Berggren method. J. Therm. Anal. Calorim., 135, 2287-2296.

[14] Málek, J. (1992). The kinetic analysis of nonisothermal data. Thermochim. Acta, 200, 257-269.

[15] Ceylan, S. (2015). Kinetic analysis on the nonisothermal degradation of plum stone waste by thermogravimetric analysis and integral Master- 
Plots method. Waste Manag. Res., 33(4), 345352.

[16] Dilmaç, N. (2021). Isothermal and non-isothermal reduction kinetics of iron ore oxygen carrier by CO: Modelistic and model-free approaches. Fuel, 296, 1-11.

[17] Lv, X., Lv, W., Wang, L., \& Qiu, J. (2017). Thermal analysis kinetics of the solid-state reduction of nickel laterite ores by carbon. Miner. Met. Mater. Ser., 8, 147-160.

[18] Zhang, Y., Wei, W., Yang, X., \& Wei. F. (2013). Reduction of $\mathrm{Fe}$ and $\mathrm{Ni}$ in $\mathrm{Fe}-\mathrm{Ni}-\mathrm{O}$ systems. $J$. Min Metall. Sect. B. Metall., 49(1), 13-20.

[19] Li, B., Wang, H., \& Wei, Y. G. (2012). Kinetic analysis for non-isothermal solid state reduction of nickel laterite ore by carbon monoxide. Trans. Institutions Min. Metall. Sect. C Miner. Process. Extr. Metall., 121(3), 178-184.
[20] Liu, Y., Lv, X., You, Z., \& Lv, X. (2020). Kinetics study on non-isothermal carbothermic reduction of nickel laterite ore in presence of $\mathrm{Na}_{2} \mathrm{SO}_{4}$. Powder Technol., 362, 486-492.

[21] Pickles, C. A., Forster, J., \& Elliott, R. (2014). Thermodynamic analysis of the carbothermic reduction roasting of a nickeliferous limonitic laterite ore. Miner. Eng., 65, 33-40.

[22] Janković, B., Adnadević, B., \& Mentus, S. (2007). The kinetic analysis of non-isothermal nickel oxide reduction in hydrogen atmosphere using the invariant kinetic parameters method. Thermochim. Acta, 456(1), 48-55.

[23] Janković, B., Adnadević, B., \& Mentus, S. (2008). The kinetic study of temperature-programmed reduction of nickel oxide in hydrogen atmosphere. Chem. Eng. Sci., 63, 567-575. 